\title{
Hubungan Pelaksanaan Penggunaan APD terhadap Kecelakaan Kerja di JOB Pertamina Talisman Jambi Merang
}

\author{
Peppy Herawati ${ }^{1 *}$, Reza Khulaifi ${ }^{1}$ \\ ${ }^{1}$ Program Studi Teknik Lingkungan Universitas Batanghari \\ Jalan Slamet Riyadi, Broni, Kota Jambi \\ *e-mail : peppy.herawati@unbari.ac.id
}

\begin{abstract}
This research is focused to approach at the relationship between the implementation of personal protective equipment (PPE) to safety programme with employee, where PPE is used as a last resort in an effort to protect workers if the effort to control the elimination of danger sources, equipment substitution, engineering and administration but the potential risk is still relatively high. This research is focused on associative descriptive with correlation approach, which uses a questionnaire of 80 employees in the JOB Pertamina Talisman Jambi Merang production department engaged in the oil and gas industry located in Bayung Lencir, South Sumatra Province. The results of this study use a bivariate analysis test looking for the relationship between the application of personal protective equipment (PPE) with workplace accidents at the job accident on the crew driling the repair part of the well maintenance at the RPS 05 rig, PT.Pertamina EP Asset 1 Field Jambi. The study found that there was a significant relationship between the variables of K3 inspection and personal protective equipment (PPE) against work accidents. with a value $(r)$ of 0.722 which means a significant relationship between the commitment to carry out $K 3$ inspection and personal protective equipment (PPE). (PPE).
\end{abstract}

Keywords: Bivariate statistical test; PPE; Work accident.

\section{Pendahuluan}

Keselamatan dan Kesehatan Kerja karyawan merupakan salah satu hak asasi dan salah satu upaya untuk meningkatkan kualitas kinerja karyawan di perusahaan itu sendiri. Perusahaan bisa mencegah kecelakaan tersebut jika perusahaan memberikan pelayanan K3 yang baik terhadap karyawannya serta memberi jaminan atas kecelakaan tersebut. Sehingga para karyawan merasa aman dan terlindungi dengan adanya program K3 yang terlaksana di perusahaan tersebut karena kecelakaan kerja merupakan kejadian yang tidak terduga sebelumnya dan tidak diketahui kapan terjadi. Upaya pencegahan kecelakaan kerja pada dasarnya telah diatur dalam Peraturan Pemerintah Republik Indonesia Nomor 50 Tahun 2012 tentang Penerapan Sistem Manajemen Keselamatan dan Kesehatan Kerja, yaitu bagian dari sistem manajemen perusahaan secara keseluruhan dalam rangka pengendalian risiko yang berkaitan dengan kegiatan kerja guna tercipta suatu tempat kerja yang aman, efisien dan produktif.

Sementara dari data International Labour Organization (ILO) tahun 2015, 1 pekerja di dunia meninggal setiap 15 detik karena kecelakaan kerja dan 160 pekerja mengalami sakit akibat kerja. Tahun (2016) ILO mencatat angka kematian dikarenakan kecelakaan dan penyakit akibat kerja (PAK) sebanyak 2 juta kasus setiap tahun (Kemenkes, 2017). Job Pertamina-Talisman telah berkomitmen penuh terhadap penerapan $\mathrm{K} 3$ diseluruh jenis pekerjaan sejak fase konstruksi pada tahun 2007. Namun pada kondisi sehari -harinya masih terjadi kejadian kecelakaan kerja, Hal ini didukung oleh data-data kecelakaan kerja 3 tahun yang lalu,yaitu tahun 2015 terjadi 7 kecelakaan kerja, tahun 2016 terjadi 10 kecelakaan kerja dan tahun 2017 terjadi 5 kali kecelakaan kerja, (Jambi Merang Healt Safety Security Environment Document,2017). Dari data potensi bahaya diatas, penyebab kecelakaan kerja yang terjadi di area Job Pertamina-Talisman dibagi atas 2 garis besar yaitu akibat kondisi tempat kerja (Unsafe Condition) sebanyak 8 kali kejadian atau $36.4 \%$, dan akibat manusia/perbuatan sub standar (Unsafe Human Act) sebanyak 14 kali kejadian atau 63.6\%, (Jambi Merang Healt Safety Security Environment Document,2017). Faktor-faktor kondisi tempat kerja adalah situasi atau keadaan yang tidak langsung disebabkan oleh tindakan atau ketidaksengajaan dari satu atau lebih karyawan pada suatu lokasi yang dapat menyebabkan celaka atau cedera jika kondisi tersebut tidak diperbaiki, dan faktor manusia/perbuatan sub standar adalah tindakan atau perilaku yang tidak perlu dilakukan dalam melakukan pekerjaan dimana tindakan tersebut dapat meningkatkan kemungkinan celaka atau cedera jika tidak diubah.

\section{Metode Penelitian}

Jenis penelitian ini adalah penelitian dengan metode kuantitatif dan menggunakan analisis deskriptif asosiatif dengan pendekatan korelasi. Penelitian ini dilakukan untuk mengetahui hubungan Komitmen Pelaksanaan Inspeksi K3 dan Pemakaian Alat Pelindung Diri terhadap tingkat kecelakaan kerja di Job Pertamina-Talisman Jambi Merang. Pengukuran persepsi ini dilakukan dengan menggunakan skala Likert (skala 1 menyatakan persepsi sangat tidak setuju sampai dengan skala 4 untuk menyatakan persepsi sangat setuju) terhadap setiap pernyataan dalam kuesioner, Adapun prosedur pengambilan data penelitian ini dilakukan melalui langkah penentuan sampel dari populasi penelitian dengan mengacak perbedaan posisi kerja dan jabatan dari karyawan produksi dan perawatan di JOB Pertamina-Talisman Jambi Merang. Adapun jumlah populasi karyawan produksi dan perawatan Job Pertamina-Talisman Jambi Merang yaitu 80 orang dengan rincian karyawan produksi sebanyak 50 orang, dan perawatan (maintenance) sebanyak 30 orang. Adapun rincian analisis data yang dilakukan adalah mendeskripsi karakteristik responden penelitian, analisis asosiatif, Analisis uji normalitas data sebaran hubungan antar variabel penelitian, Analisis bivariat digunakan untuk menguji hipotesis penelitian. 


\section{Hasil dan Pembahasan}

\subsection{Deskripsi Karakteristik Responden}

Untuk menganalisis data kuisioner yang terkumpul sehingga dapat mengidentifikasi karakteristik masingmasing responden dengan menggunakan rata-rata skor pembobotan, pada analisa deskriptif ini menggunakan skala likert dengan memberi nilai skor pada tiap-tiap pernyataan. Berdasarkan pengelompokan hasil Kuisioner terhadap Inspeksi K3 maka sesuai dengan kisi-kisi kuisioner secara garis besar maka didapat

Tabel 1. Hasil Kuesioner Inspeksi K3

\begin{tabular}{cccc}
\hline No. & $\begin{array}{l}\text { Item pernyataan } \\
\text { dengan Indikator }\end{array}$ & $\begin{array}{c}\text { Jumlah skor } \\
\text { setuju Komitmen } \\
\text { Pelaksanaan } \\
\text { Inspeksi K3 per } \\
\text { indikator }\end{array}$ & $\begin{array}{c}\text { Persentase } \\
\text { dari } 60 \\
\text { responden }\end{array}$ \\
\hline 1 & $\begin{array}{l}\text { Inspeksi Terkait } \\
\text { Peralatan dan } \\
\text { Mesin }\end{array}$ & 782 & 26,97 \\
Inspeksi & $\begin{array}{l}\text { Lingkungan Kerja } \\
\text { Inspeksi } \\
\text { Komitmen dan } \\
\text { Kompetensi }\end{array}$ & 1120 & 34,39 \\
\hline & & 38,63 \\
\hline TOTAL SKOR & 2899 & 100,00 \\
\hline
\end{tabular}

Tabel 1 memperlihatkan dari 80 responden yang menjawab Setuju untuk 3 indikator pernyataan tentang Inspeksi K3 yaitu :

1. Untuk indikator inspeksi $\mathrm{K} 3$ terkait peralatan dan mesin yang menjawab setuju sebanyak $26,97 \%$.

2. Untuk indikator Inspeksi K3 terkait lingkungan kerja yang menjawab setuju sebanyak $34,39 \%$.

3. Untuk indikator Inspeksi K3 terkait komitmen dan kompetensi yang menjawab setuju sebanyak 38,63\%.

Dari hasil kuesioner tersebut, dapat dilihat bahwa mayoritas responden setuju dengan pernyataan bahwa inspeksi komitmen K3 dan kompetensi berpengaruh untuk mencegah terjadinya kecelakaan kerja di lingkungan JOB Pertamina Talisman Jambi Merang.

Berdasarkan pengelompokan hasil Kuisioner terhadap Penggunaan Alat Pelindung Diri (APD). Didalam variabel penggunaan APD terdapat 15 pernyataan yang ada pada kuisioner, dimana kesimpulan hasil outputnya adalah sebaran jawaban pernyataan sebagai berikut.

Tabel 2. Hasil Kuesioner Penggunaan Alat Pelindung Diri

\begin{tabular}{clcc}
\hline No. & \multicolumn{1}{c}{$\begin{array}{c}\text { Pernyataan } \\
\text { dengan Indikator }\end{array}$} & $\begin{array}{c}\text { Jumlah skor } \\
\text { setuju } \\
\text { Penggunaan } \\
\text { APD per } \\
\text { indikator }\end{array}$ & $\begin{array}{c}\text { Persentase } \\
\text { dari } 60 \\
\text { responden }\end{array}$ \\
\hline 1 & Fungsi/Pemakaian & 946 & 34,45 \\
2 & APD & 1033 & 37,62 \\
3 & Standar APD & 580 & 21,12 \\
4 & Jengetahuan APD & 187 & 6,81 \\
\hline \multicolumn{7}{l}{ TOTAL SKOR } & 2746 & 100,00 \\
\hline
\end{tabular}

Tabel diatas memperlihatkan dari 80 responden yang menjawab Setuju untuk 4 indikator pernyataan tentang Pemakaian APD yaitu :

1. Untuk indikator fungsi atau pemakaian APD yang menjawab setuju sebanyak 34,45\%.

2. Untuk indikator Standar APD yang menjawab setuju sebanyak $37,62 \%$.

3. Untuk indikator pengetahuan tentang APD yang menjawab setuju sebanyak $21,12 \%$.

4. Untuk indikator jenis-jenis APD yang menjawab setuju sebanyak $6,81 \%$.

Dari hasil kuesioner tersebut, dapat dilihat bahwa mayoritas responden setuju dengan pernyataan bahwa pemakaian APD berpengaruh untuk mencegah terjadinya kecelakaan kerja di lingkungan JOB Pertamina Talisman Jambi Merang.

Variabel ketiga dalam penelitian ini adalah Kecelakaan Kerja. Didalam variabel kecelakaan kerja terdapat 15 pernyataan yang ada pada kuisioner, dimana hasil dari kuisioner mengenai kecelakaan kerja secara garis besar adalah

Tabel 3. Hasil Kuesioner Kecelakaan Kerja

\begin{tabular}{clcc}
\hline No. & $\begin{array}{c}\text { Item pernyataan } \\
\text { dengan } \\
\text { Indikator }\end{array}$ & $\begin{array}{c}\text { Jumlah skor setuju } \\
\text { Kecelakaan Kerja } \\
\text { per indicator }\end{array}$ & $\begin{array}{c}\text { Persentase } \\
\text { dari } 60 \\
\text { responden }\end{array}$ \\
\hline 1 & $\begin{array}{l}\text { Potensi Bahaya } \\
\text { dari Peralatan }\end{array}$ & 2822 & 86,64 \\
2 & $\begin{array}{l}\text { Kerja } \\
\text { Potensi Bahaya } \\
\text { dari } \\
\text { Lingkungan } \\
\text { Kerja }\end{array}$ & 435 & 13,36 \\
\hline TOTAL SKOR & 3257 & 100,00 \\
\hline
\end{tabular}

Tabel 3 memperlihatkan dari 80 responden yang menjawab Setuju untuk 2 indikator pernyataan tentang Kecelakaan kerja yaitu :

1. Untuk indikator potensi bahaya dari peralatan kerja yang menjawab setuju sebanyak $86,64 \%$.

2. Untuk indikator potensi bahaya dari lingkungan kerja yang menjawab setuju sebanyak $13,36 \%$.

Dari hasil kuesioner tersebut, dapat dilihat bahwa mayoritas responden setuju dengan pernyataan bahwa responden mengerti mengenai potensi bahaya yang timbul dari peralatan kerja di lingkungan JOB Pertamina Talisman Jambi Merang.

\subsection{Hasil Uji Normalitas Data Dengan Kolmogrov- Smirnov}

Setelah diketahui nilai rata-rata setiap variabel, maka selanjutnya dilakukan uji distribusi normal variabel rata-rata inspeksi K3, penggunaan APD dan kecelakaan kerja yang dialami oleh karyawan JOB Pertamina-Talisman Jambi Merang yang berguna untuk mengetahui apakah data berdistribusi normal atau tidak. Dari hasil uji kenormalan dengan Kolmogrov-Smirnov data tersebut normal jika diperoleh nilai signifikannya lebih dari $0,05(>0,05)$, dapat disimpulkan bahwa data variabel rata-rata komitmen pelaksanaan inspeksi K3 dan pemakian Alat Pelindung Diri di JOB Pertamina-Talisman Jambi Merangberdistribusi 
normal. Sehingga memenuhi untuk dilanjutkan dengan melakukan penelitian selanjutnya.

\subsection{Hasil Analisis Bivariat}

Analisis bivariat digunakan untuk mengetahui apakah inspeksi K3, penggunaan APD (variabel terikat) ada hubungannya dengan kecelakaan kerja (variabel bebas) di JOB Pertamina-Talisman Jambi Merang. Untuk menguji korelasi ( hubungan) antara masing- masing variabel bebas dan variabel terikat digunakan dua pengujian hipotesis yaitu pengujian hipotesis deskriptif dengan uji korelasi Pearson Product Moment (r). Taraf signifikasi uji hipotesis yang digunakan adalah 0,05 artinya hasil uji hipotesis untuk membuktikan ada pengaruh atau hubungan sangat signifikan bila taraf signifikan kurang atau sama dengan 0,05 ( $\alpha \leq$ $0,05)$ dan apabila taraf signifikan lebih dari $0,05(\alpha>0,05)$ maka pengaruh atau hubungan dikatakan tidak signifikan yang dapat dilihat pada Tabel 4, dengan Hipotesis sebagai berikut :
a. Ha: Tidak ada hubungan negatif inspeksi K3, penggunaan APD dengan kecelakaan kerja
b. Ho: Ada hubungan negatif inspeksi K3, penggunaan APD dengan kecelakaan kerja.
c. Statistik uji: uji korelasi
d. $\operatorname{Sign} \alpha=0,05$

Tabel 4. Model Summary ${ }^{\mathrm{b}}$

\begin{tabular}{|c|c|c|c|c|c|c|c|c|c|}
\hline \multirow[b]{2}{*}{ Model } & \multirow[b]{2}{*}{$\mathrm{R}$} & \multirow[b]{2}{*}{ R Square } & \multirow[b]{2}{*}{$\begin{array}{c}\text { Adjusted R } \\
\text { Square }\end{array}$} & \multirow[b]{2}{*}{$\begin{array}{l}\text { Std. Error of } \\
\text { the Estimate }\end{array}$} & \multicolumn{5}{|c|}{ Change Statistics } \\
\hline & & & & & $\begin{array}{l}\text { R Square } \\
\text { Change }\end{array}$ & F Change & df1 & df2 & Sig. F Change \\
\hline 1 & $.722^{\mathrm{a}}$ & .521 & .504 & 3.080 & .521 & 30.996 & 2 & 57 & .000 \\
\hline
\end{tabular}

\section{a. Predictors: (Constant), ALAT PELINDUNG DIRI, INSPEKSI K3 \\ b. Dependent Variable: KECELAKAAN KERJA}

Dari tabel diatas dapat dilihat bahwa nilai signifikan $<0,05$, berarti data tersebut berkorelasi atau terdapat hubungan yang signifikan antara variabel komitmen pelaksanaan inspeksi K3 dan Alat Pelindung Diri (APD) terhadap Kecelakaan Kerja. Yang mana didapat nilai korelasi (r) sebesar 0,722 yang menunjukkan hubungan antara komitmen pelaksanaan inspeksi K3 dan Alat Pelindung Diri (APD) terhadap Kecelakaan Kerja diinterpretasikan kuat karena berada diantara rata-rata $0,61-0,80$.

\subsection{Uji Hipotesis}

Uji t digunakan untuk mengetahui apakah variabel variabel independen berpengaruh secara individual terhadap variabel dependen. Nilai signifikan yang digunakan adalah 0,05 . Jika nilai signifikan yang dihasilkan uji $\mathrm{t}<0,05$, maka dapat disimpulkan bahwa variabel independen berpengaruh signifikan terhadap variabel dependen.

Untuk melihat pengaruh Inspeksi K3 maka dilakukan analisis linier untuk mengetahui ada tidaknya pengaruh dari variabel bebas terhadap variabel terikat. Sehingga terlihat variabel bebas ( independen variable) yaitu Inspeksi K3 $\left(\mathrm{X}_{1}\right)$, Penggunaan APD (Alat pelindung diri) $\left(\mathrm{X}_{2}\right)$ mempunyai pengaruh terhadap variabel terikat (dependen variable) yaitu Kecelakaan Kerja (Y).

Tabel 5. Pengaruh Variabel

Coefficients $^{\mathrm{a}}$

\begin{tabular}{|c|c|c|c|c|c|}
\hline \multirow[b]{2}{*}{ Model } & \multicolumn{2}{|c|}{ Unstandardized Coefficients } & \multirow{2}{*}{$\frac{\text { Standardized Coefficients }}{\text { Beta }}$} & \multirow[b]{2}{*}{$\mathrm{T}$} & \multirow[b]{2}{*}{ Sig. } \\
\hline & B & Std. Error & & & \\
\hline $1 \quad$ (Constant) & 27.331 & 4.477 & & 6.105 & .000 \\
\hline INSPEKSI K3 & -.557 & .155 & -.557 & -3.600 & .001 \\
\hline ALAT PELINDUNG DIRI & 1.008 & .143 & 1.090 & 7.051 & .000 \\
\hline
\end{tabular}

a. Dependent Variable: KECELAKAAN KERJA

Jika nilai signifikan lebih kecil dari derajat kepercayaan maka hipotesis alternatif diterima, dengan pernyataan sebagai berikut :

1. Inspeksi Pelaksanaan K3 terhadap Kecelakaan Kerja

Berdasarkan tabel 3.5 dapat dilihat jika nilai signifikan Inspeksi Pelaksanaan K3 sebesar 0,001. Ini berarti nilai signifikan lebih kecil dari nilai probabilitas 0,05 atau nilai $0,001<0,05$, maka terdapat pengaruh signifikan dan positif terhadap variabel Kecelakaan Kerja. Jadi dapat disimpulkan bahwa Inspeksi K3 memiliki pengaruh yang signifikan terhadap Kecelakaan Kerja.

2. Alat Pelindung diri (APD) terhadap Kecelakaan Kerja
Berdasarkan tabel diatas dapat dilihat jika nilai signifikan Alat Pelindung diri (APD) sebesar 0,000. Ini berarti nilai signifikan lebih kecil dari nilai probabilitas 0,05 atau nilai $0,000<0,05$, maka terdapat pengaruh signifikan dan positif terhadap variabel Kecelakaan Kerja. Jadi dapat disimpulkan bahwa Alat Pelindung diri (APD) memiliki pengaruh yang signifikan terhadap Kecelakaan Kerja.

\section{Kesimpulan}

Berdasarkan hasil penelitian yang dilakukan dapat disimpulkan bahwa hubungan pelaksanaan inspeksi K3 dan 
alat pelindung diri (APD) mempunyai hubungan. Hubungan antara variable bebas dan terikat disimpulkan dalam uraian berikut :

1. Uji kenormalan dengan Kolmogrov-Smirnov diperoleh data pelaksanaan inspeksi K3 dan alat pelindung diri (APD) normal, karena nilai signifikannya> 0,05. Yaitu sebesar $0,078>0,05$ yang berarti nilai residual terdistribusi secara normal.

2. Terdapat hubungan yang signifikan antara variabel pelaksanaan inspeksi K3 dan alat pelindung diri (APD) terhadap kecelakaan kerja. dengan nilai ( $\mathrm{r}$ ) sebesar 0,722 yang berarti hubungan antara komitmen pelaksanaan inspeksi K3 dan alat pelindung diri (APD) terhadap kecelakaan kerjadi interpretasikan kuat karena berada diantara rata-rata $0,61-0,80=$ kuat.

\section{Daftar Pustaka}

Achmadi, U.F. 1998. Analisis Resiko Kecelakaan kerja, studi kasus Industri X di Cakung Jakarta, LPUI

Abdurrahman dan Muhidin. 2007. Analisis Korelasi, Regresi dan JAlur dalam penelitian. Bandung.Pustaka Setia

Creswell, J.W. 2008. Research Design, Pendekatan kualitatif, Kuantitatif dan Mixed, Edisi Ketiga Pustaka Pelajar Bandung

Eka, K.P. 2015. Hubungan Implementasi ISO 14001 Terhadap Kinerja Karyawan Di PT PLN Pembangkitan Sumatra Bagian Selatan Sektor Pengedalian Pembangkitan Jambi

Emzir. 2007. Metodologi Penelitian Pendidikan Kuantitatif dan Kualitatif, Jakarta PT Raja Grafindo Persada

Santoso, G. 2004. Manajemen Keselamatan dan Kesehatan Kerja, Jakarta Cetakan pertama Prestasi Pustaka

Notoatmodjo, S.(2007) Pendidikan dan Perilaku kesehatan cetakan kedua, Jakarta . PT. Rineka Cipta

Salim, E. 2002. Green Company : Pedoman Pengelolaan Lingkungan Kesehatan dan Keselamatan Kerja (LK3) Jakarta. PT Astra Internasional Tbk

Sucipto, C. 2014. Keselamatan dan Kesehatan Kerja Yogyakarta, Gosyen Publishing.

Sugiyono. 2010. Metode Penelitian Kuantitatif, Kualitatif dan R\&D. Bandung Alfabeta

Suma'mur, P.K. 1989. Keselamatan Kerja Pencegahan Kecelakaan, Jakarta PT Gunung Agung

Sussyanto, D. 2014. Hubungan Alat Pelindung Diri Dengan Kecelakaan Kerja. TA Teknik Lingkungan Universitas Batanghari

Yunizar. 2008. Pengetaahuan dan Keselamatan Kerja (K3), Penggunaan Alat Pelindung Diri dan Pelaksanaan Inspeksi K3 dengan Kecelakaan Kerja pada crew Driling Di PT Pertamina. Tesis Pascasarjana UGM 